\title{
Erythropoiesis stimulating agents: approaches to modulate activity
}

\author{
This article was published in the following Dove Press journal: \\ Biologics:Targets and Therapy \\ 2 July 2013 \\ Number of times this article has been viewed
}

\author{
Angus M Sinclair \\ Amgen Inc, Thousand Oaks, \\ CA, USA
}

Correspondence: Angus M Sinclair Amgen Inc, I Amgen Center Drive, Thousand Oaks, CA 91320-1799, USA

$\mathrm{Tel}+\mathrm{I} 8054477$ I38

Fax +l 8054990953

Email anguss@amgen.com

\begin{abstract}
Recombinant human erythropoietin ( $\mathrm{rHuEPO}$ ), such as the approved agents epoetin alfa and epoetin beta, has been used successfully for over 20 years to treat anemia in millions of patients. However, due to the relatively short half-life of the molecule (approximately 8 hours), frequent dosing may be required to achieve required hemoglobin levels. Therefore, a need was identified in some anemic patient populations for erythropoiesis stimulating agents with longer half-lives that required less frequent dosing. This need led to the development of second generation molecules which are modified versions of rHuEPO with improved pharmacokinetic and pharmacodynamic properties such as darbepoetin alfa, a hyperglycosylated analog of rHuEPO, and pegzyrepoetin, a pegylated rHuEPO. Third generation molecules, such as peginesatide, which are peptide mimetics that have no sequence homology to rHuEPO have also recently been developed. The various molecular, pharmacokinetic, and pharmacodynamic properties of these and other erythropoiesis stimulating agents will be discussed in this review.
\end{abstract}

Keywords: darbepoetin alfa, erythropoiesis, erythropoietin, glycosylation, pharmacokinetics, pharmacology, polyethylene glycols

\section{Introduction}

Anemia is a condition whereby the number of red blood cells, the amount of hemoglobin in blood, and/or the volume of packed red blood cells is lower than normal. Anemia frequently occurs in patients with renal failure, cancer, and other conditions, such as HIV infection. The treatments for anemia include transfusion, iron supplementation, and dosing with erythropoiesis stimulating agents (ESAs). Along with the benefits of each of these treatment options, there are potential safety risks that are reviewed elsewhere. ${ }^{1,2}$ Red blood cell production, the process of erythropoiesis, occurs in the bone marrow and is controlled by the natural hormone erythropoietin (EPO), a 165 amino acid glycoprotein primarily produced by interstitial fibroblasts in the kidney. ${ }^{3}$ The EPO molecule has a compact globular structure that contains one O-linked and three $\mathrm{N}$-linked carbohydrate side chains that constitute approximately $40 \%$ of its mass. ${ }^{3}$ EPO production is regulated at the transcriptional level by hypoxia inducible transcription factor (HIF) subunits HIF-1 $\alpha$ and HIF-2 $\alpha$, part of the cellular oxygen sensory machinery. ${ }^{4}$ Under normal conditions, the HIF- $\alpha$ transcription factor proteins are produced but are rapidly hydroxylated by HIF prolylhydroxylases and targeted for degradation by the Von Hippel Lindau complex before having the ability to activate transcription of the EPO gene. However, under low oxygen conditions, the HIF- $\alpha$ proteins are not hydroxylated and are therefore stabilized, and able to bind to the DNA regulatory elements (hypoxia regulatory elements) of the EPO gene and 
activate $E P O$ gene transcription and consequently protein production. Pharmacologic modulation of the HIF- $\alpha$ proteins has recently been investigated as an approach to treat anemia ${ }^{4}$ but will not be discussed in this review.

EPO acts on early erythroid progenitors resident in the bone marrow, along with other cytokines, to promote erythroid progenitor survival, proliferation, and differentiation into mature erythrocytes (Figure 1). ${ }^{3}$ Hematopoietic stem cells resident in the bone marrow differentiate into multiple myeloid and lymphoid lineages, including the erythroid lineage. The earliest committed erythroid progenitors are classified as burst forming units-erythroid. It is these erythroid progenitors that upregulate the expression of the erythropoietin receptor (EPOR) and become responsive to EPO. The EPO:EPOR interaction induces signaling cascades that induce the differentiation of these progenitors to form colony forming units-erythroid, which themselves are highly responsive to EPO. EPO induces the expansion and further differentiation of colony forming units-erythroid cells into proerythroblasts and erythroblasts. Erythroblasts extrude their nuclei and form reticulocytes that are released from the bone marrow into the circulation and subsequently terminally differentiate into hemoglobin containing erythrocytes. In healthy humans, erythrocytes have a lifespan of approximately 100 to 120 days.
EPOR is a type-1, single transmembrane receptor that exists in preformed homodimers on the cell surface. ${ }^{5}$ Two regions of the EPO molecule have been shown to bind EPOR, one with a high affinity $(\sim \mathrm{Km} 1 \mathrm{nM})$ and the other a low affinity site $(\sim \mathrm{Km} 1 \mu \mathrm{M}){ }^{6}$ A single EPO molecule is proposed to bind to the high affinity EPOR site first and then bind to the other EPOR molecule through the second lower affinity site. The generation of EPOR protein and subsequent trafficking to the cell surface is an inefficient process with only $1 \%-10 \%$ of total cellular EPOR molecules being trafficked to the membrane. ${ }^{7-11}$ A key accessory protein is Janus kinase-2 (JAK2) which binds EPOR in the endoplasmic reticulum, induces correct protein folding, promotes surface expression, and is essential for EPOR signaling. ${ }^{12}$ Binding of EPO to EPOR induces a receptor conformational change, which brings two receptor-associated JAK2 molecules into close proximity. ${ }^{13}$ Transphosphorylation of JAK2 results in phosphorylation of tyrosine residues located within the cytoplasmic tail of EPOR, which serve as docking sites for signaling adaptor proteins. ${ }^{14,15}$ EPOR stimulation induces the activation of signal transducer and activator of transcription-5 (STAT5), phosphoinositol 3'-kinase (PI3K), the MAP kinase (MAPK), and protein kinase C (PKC) pathways. ${ }^{14,15}$ These signaling pathways promote the survival, differentiation

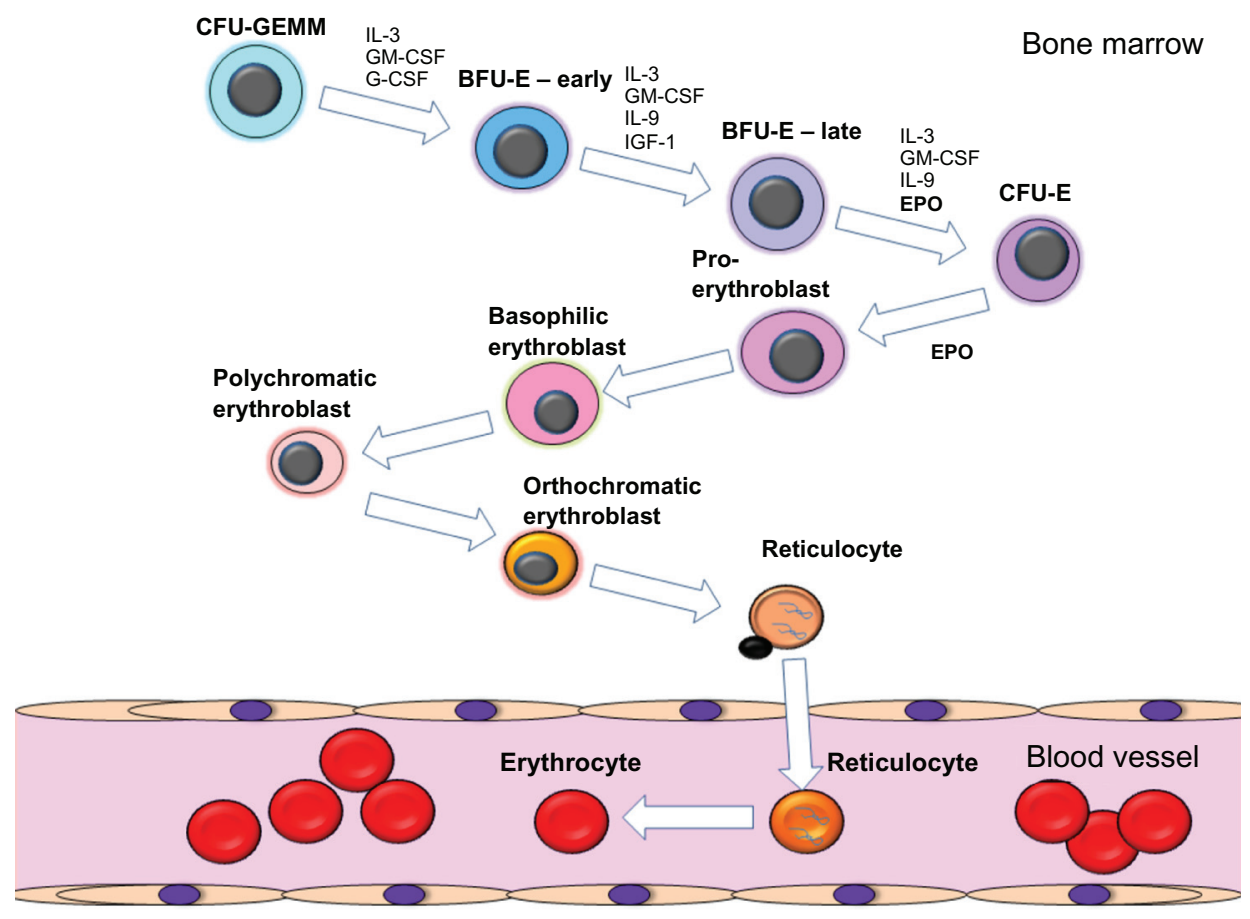

Figure I Schematic diagram of the process of erythropoiesis. The various stages of erythroid differentiation are shown including the key cytokines that are involved in the proliferation, survival and differentiation of the erythroid progenitors.

Abbreviations: BFU-E, burst forming unit-erythroid; CFU-E, colony forming unit-erythroid; CFU-GEMM, colony forming unit-granulocyte, erythroid, macrophage, megakaryocyte; EPO, erythropoietin; G-CSF, granulocyte colony stimulating factor; GM-CSF, granulocyte monocyte colony stimulating factor; IL-3, interleukin 3; IL-9, interleukin 9, IGF-I, insulin-like growth factor I. 
and proliferation of the erythroid progenitors. A number of molecules have been implicated in the negative regulation of EPOR signaling including, Src homology region 2 domaincontaining phosphatase 1 (SHP-1), and suppressor of cytokine signaling proteins SOCS-1 and SOCS-3. ${ }^{16,17}$ Absence of negative regulation of EPOR signaling is associated with familial polycythemia due to cytoplasmic truncations of EPOR that remove SHP-1 and other suppressor binding sites. ${ }^{18,19}$ Though other receptor complexes have been suggested for EPO, these data are controversial and are reviewed elsewhere. ${ }^{2}$

\section{Glycosylation of recombinant human EPO (rHuEPO)}

In 1985, two independent groups reported the cloning of the human erythropoietin gene..$^{20,21}$ The use of rHuEPO was approved in 1988 and 1989 in Europe and the USA, respectively for the treatment of anemia associated with renal insufficiency, and subsequently approved for anemia associated with myelosuppressive chemotherapy associated with cancer treatment. $\mathrm{rHuEPO}$ protein is produced in genetically engineered Chinese Hamster Ovary cells and has a molecular weight of $30.4 \mathrm{kDa}$ and is composed of $\sim 60 \%$ amino acids and $\sim 40 \%$ carbohydrates. ${ }^{22}$ Like naturally occurring EPO, rHuEPO consists of a 165 amino acid single polypeptide chain and contains three N-linked glycosylation sites at asparagine residues (Asn24, Asn38, Asn83) and one O-linked site at serine residue Ser126. ${ }^{21,23,24} \mathrm{rHuEPO}$ produced in African green monkey kidney cell line (COS1) and Chinese Hamster Ovary cells was shown to have a biologic activity equivalent to that of endogenous human EPO in both in vitro and in vivo assays. ${ }^{24}$ Until recently, the use of mammalian cell lines was critical for the production of rHuEPO. This was due to the requirement for specific glycosyltransferases and glycosidases for glycan biosynthesis for the correct glycosylation of rHuEPO. The process of glycosylation, unlike the synthesis of amino acids and nucleic acids, is enzymatic rather than defined by a template, and hence the carbohydrates are diverse with respect to both the number and the linkage patterns of the sugar units. ${ }^{25}$ Indeed, the carbohydrate composition of rHuEPO N-linked chains is complex and differs in terminal $\mathrm{N}$-acetylneuraminic acid (Neu5Ac) content, O-acetylation of the Neu5Ac residues, $\mathrm{N}$-acetylactosamine extensions, and degree of branching. ${ }^{26,27}$ Thus, changes in cell lines, growth conditions, or manufacturing processes can affect the final rHuEPO characteristics, including the generation of microheterogeneity in glycosylation. ${ }^{28}$ Carbohydrate addition to proteins can influence many aspects of a protein's properties including molecular stability, solubility, immunogenicity, and in vitro and in vivo biological activity. These properties are described below.

\section{Molecular stability}

A protein therapeutic needs to be stable in order to maintain activity and reduce the potential for immunogenicity. Glycosylation can play an important role in maintaining molecular integrity and can reduce the potential for proteolysis. For example, the carbohydrate on rHuEPO helps maintain molecular integrity and activity. The in vitro biological activities of asialo-rHuEPO and fully deglycosylated rHuEPO were reduced to $35 \%$ and $11 \%$ of initial activity respectively upon heat treatment, whereas glycosylated rHuEPO lost no activity. ${ }^{29}$ Under denaturing conditions, such as guanidine- $\mathrm{HCl}$, heat, and acidic $\mathrm{pH}$, unglycosylated rHuEPO was more readily aggregated and precipitated, whereas glycosylated rHuEPO was able to refold and remain soluble. ${ }^{30,31}$ Furthermore, the peptide component of $\mathrm{rHuEPO}$ was protected from oxygen free radical damage if glycosylated. ${ }^{32}$

\section{Solubility}

The solubility of hydrophobic proteins can be increased by the addition of highly hydrophilic sialic acid containing carbohydrates. ${ }^{33}$ For example, unglycosylated Plasmodium falciparum merozoite surface protein 1 (MSP-1) was considerably more insoluble than glycosylated MSP-1 when purified from transgenic mouse milk. ${ }^{34}$ Unglycosylated MSP-1 was also found to be significantly more immunogenic in monkeys challenged with a lethal infection of $P$. falciparum when used as a vaccine than glycosylated MSP- $1 .{ }^{34}$ This may have been due to the formation of aggregates and precipitates of the unglycosylated protein that mounted an elevated immune response compared to the glycosylated protein. Alternatively, the carbohydrate may have "shielded" the protein from immune surveillance.

\section{Immunogenicity}

In rare cases, antibodies to administered rHuEPO are produced in patients that recognize and neutralize endogenously produced EPO, resulting in the development of antibody mediated pure red cell aplasia (PRCA) ${ }^{35}$ Outside the United States, an increase in PRCA incidence was observed between 1998 to 2004 and was associated with the administration of a human serum albumin (HSA)-free EPREX1 (recombinant human epoetin alfa) formulation. ${ }^{36}$ The potential causes of the increased immunogenicity of rHuEPO to induce PRCA in these formulations have been discussed in the literature 
and included leachates from syringe rubber plungers, use of silicone, micelle formation, and formation of aggregates through mishandling and use of polysorbate 80 in the formulation. ${ }^{37}$ However, the true cause for the increase in PRCA remains unproven. Interestingly, it was reported that the immunoreactivity of anti-rHuEPO antibodies in PRCA patient sera was elevated when carbohydrate was removed suggesting that glycosylation can "shield" the underlying protein sequences from the immune system. ${ }^{35} \mathrm{~A}$ single triantennary sialylated complex carbohydrate occupies a large volume, approximately $2542 \AA .{ }^{38}$ Therefore, the protein surface area subjected to immune surveillance would be reduced in glycosylated proteins. Indeed, carbohydrates reduced polyclonal and monoclonal antibody immunoreactivity to rHuEPO. ${ }^{39}$ Similar immune surveillance "shielding" effects of carbohydrate have been reported in other polypeptides such as asparaginase,${ }^{40}$ wasp venom peptide, ${ }^{41}$ and $P$. falciparum MSP-1 protein. ${ }^{34}$ Taken together, these studies suggest that glycosylated therapeutic proteins may have reduced immunogenicity compared to the non-glycosylated counterparts.

\section{In vitro and in vivo biological activity}

Given the large size of carbohydrates, the negative charge associated with sialic acid and the potential for steric hindrance and electrostatic repulsion, it would not be surprising if a glycosylated ligand would have a reduced binding affinity for its cognate receptor. Indeed this has been identified to be the case in rHuEPO. Studies examining the in vitro properties of various glycosylated isoforms of rHuEPO found an inverse correlation between glycan number and receptor binding affinity and in vitro biological activity (Figure 2) ${ }^{42}$ Furthermore, desialylated rHuEPO and rHuEPO synthesized in bacteria, thus lacking any glycosylation, bound EPOR with higher affinity and had a greater in vitro biological activity than fully glycosylated rHuEPO. ${ }^{43-45} \mathrm{In}$ contrast, the in vivo biological activity of rHuEPO is directly related to the number of carbohydrates and sialic acids the molecule contains, to a maximum of 14 . This was discovered by examining changes in hematocrit when groups of mice were dosed with equimolar peptide equivalents of $\mathrm{rHuEPO}$, but with different numbers of carbohydrates and sialic acids (9 to 14 ). ${ }^{42}$ A strong correlation was found between the number of sialic acids the rHuEPO molecules contained and the effect on increasing hematocrit. This was identified to be directly related to the reduced clearance and consequently increased serum half-life of molecules containing additional sialic acids. A 3- to 4-fold increase in half-life was observed when a rHuEPO molecule containing 14 sialic acids was compared to a rHuEPO molecule containing the maximum six sialic acids in mice. ${ }^{42}$

Although many studies have been conducted it is still unclear why glycosylation of rHuEPO reduces the clearance of the molecules. There are several potential routes of rHuEPO clearance that have been investigated including clearance by the kidney, hepatic clearance through the asialoglycoprotein receptor, erythroid degradation of rHuEPO after binding to and internalization by EPOR expressing cells in the bone marrow, and degradation and metabolism in the tissue interstitium. Though rHuEPO can be detected in urine, initial data suggesting that the kidney was the primary route of rHuEPO clearance were not supported by subsequent studies examining rHuEPO clearance in patients and animal models that had renal insufficiency. ${ }^{46-48}$ Indeed, only $<5 \%$ of radiolabeled epoetin beta was detected in the urine from healthy men, supporting the hypothesis that the kidney is not the primary clearance mechanism of rHuEPO. Another mechanism that has been suggested to play a role in the clearance of rHuEPO is the liver. Hepatic asialoglycoprotein receptor (ASGPR) has been reported to bind to ASGPs with subsequent internalization and degradation. Therefore the rate of desialylation of glycosylated rHuEPO was hypothesized to control clearance. ${ }^{44,45}$ However, evidence for the clearance of rHuEPO through the liver may just be relevant for asialo-rHuEPO as this mechanism has not been supported by other studies. For example, the clearance of rHuEPO in normal and liver cirrhosis patients was not different suggesting that liver ASGPR may not play a significant role in rHuEPO clearance. ${ }^{46,47,49,50}$ Other studies have also supported the finding that the liver may not play a key role in asialoprotein clearance: the saturation of the ASGPR with asialoorosomucoid did not delay the clearance of sialylated ${ }^{125}$ I-orosomucoid ${ }^{51}$ and no accumulation of desialylated glycoproteins or lipoproteins were reported in ASGPR knockout mouse circulation, though reduced clearance rates of asialoorosomucoid or asialofetuin were reported..$^{52,53}$

The bone marrow has been suggested to be a clearance organ of rHuEPO, in part through its effector function. This has been hypothesized to occur though the binding of EPO to the EPOR on erythropoietic progenitor cells and subsequent receptor mediated endocytosis and degradation in the lysosome. ${ }^{54}$ The hypothesis was supported by in vitro studies using cell lines that expressed or did not express EPOR: rHuEPO was only cleared at a significant amount from culture media containing EPOR expressing cells. ${ }^{55}$ Studies in patients receiving chemotherapy and animal models also appear to support this route of clearance 
A

UT-7/EPO thymidine incorporation assay

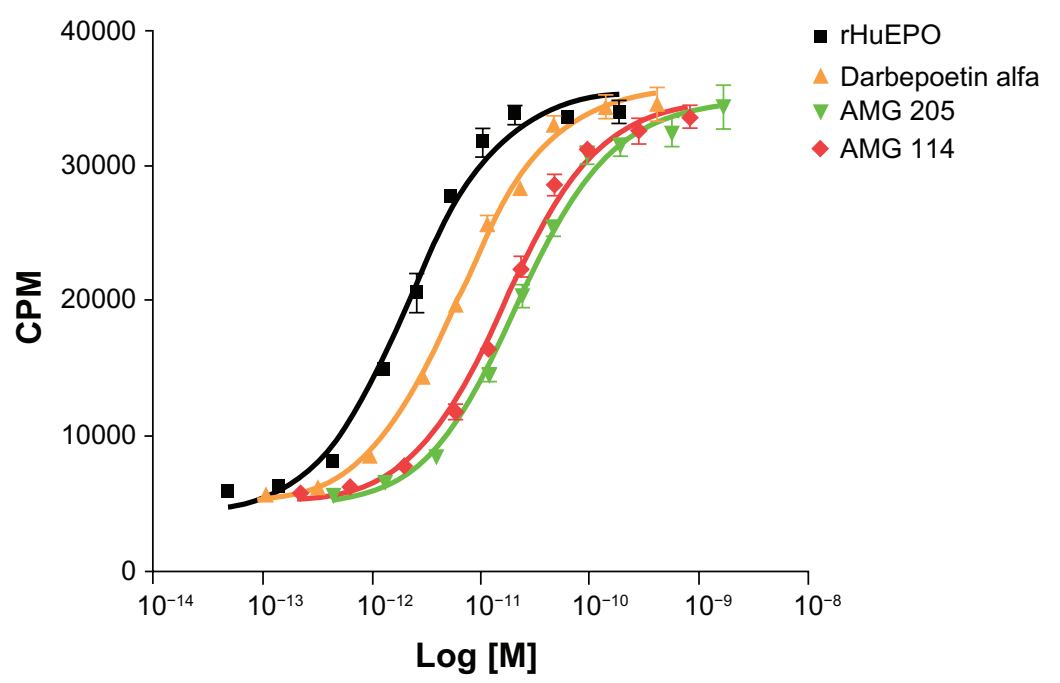

$\mathrm{EC}_{50}$

$2.1 \mathrm{pM}$

$6.0 \mathrm{pM}$

$21.0 \mathrm{pM}$

$16.2 \mathrm{pM}$

B UT-7/EPO EPOR binding assay

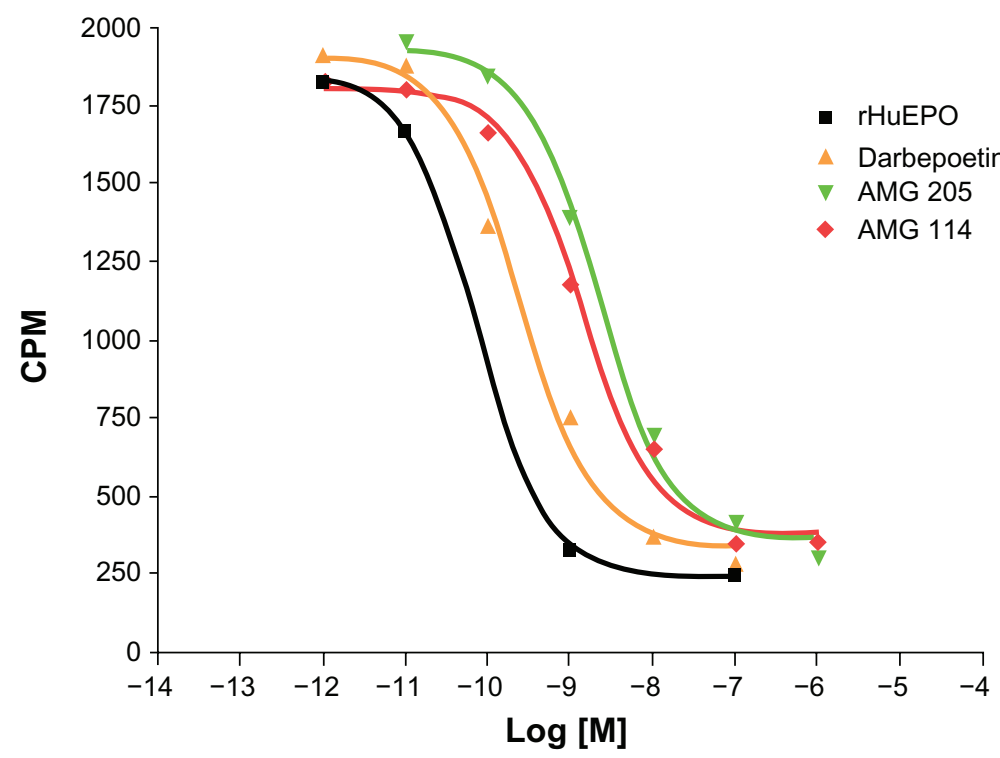

Figure 2 In vitro proliferation activity and EPOR binding activities of rHuEPO, darbepoetin alfa, AMG II4, and AMG 205 glycosylation analogs.

Notes: $(\mathbf{A}) \mathrm{H}^{3}$-thymidine incorporation assays in UT-7/EPO cells demonstrates the inverse correlation between molecules with increasing numbers of $\mathrm{N}$ linked carbohydrate ( $\mathrm{rHuEPO}=3$; darbepoetin alfa = 5; AMG II4 and AMG $205=7$ ) and decreasing in vitro proliferation activity. Proliferation is measured as counts CPM of $\mathrm{H}^{3}$-thymidine incorporation into newly synthesized DNA and $\mathrm{EC}_{50}$ values of a representative experiment are shown. (B) Competitive binding assays were performed in UT-7/EPO cells whereby ${ }^{125}$-rHuEPO was bound to cells and competed with increasing concentration of ESA for 2-3 hours. Cells were washed though phthalate oil, CMP was measured and $I_{50}$ calculated. A representative experiment is shown. Data kindly provided by Steve Elliott, Norma Rogers, and Tony Lorenzini, Amgen, Inc.

Abbreviations: CPM, counts per minute; $\mathrm{EC}_{50}, 50 \%$ effective concentration; $\mathrm{IC}_{50}, 50 \%$ inhibitory concentration; EPO, erythropoietin; $\mathrm{EPOR}$, EPO receptor; rHuEPO, recombinant human EPO.

to some degree. ${ }^{56-59}$ However, in vivo pharmacokinetic studies do not support receptor mediated endocytosis as a primary route of clearance. The comparison of half-lives of intravenous administration of rHuEPO and an EPO analog with the receptor binding sites mutated (NM385) found that NM385 had a slightly longer half-life in rats or mice but was cleared at a similar rate to rHuEPO. ${ }^{60}$ These studies suggest that receptor mediated clearance may play some role in the clearance of rHuEPO from the circulation but is not the primary route.

It is also possible that the tissue interstitium may play a role in the degradation of rHuEPO. Cells involved in the reticuloendothelial scavenging pathways or lymphatic system may play a role in the degradation or metabolism of rHuEPO. ${ }^{61}$ Therefore, the presence of glycosylation on the molecule may result in steric and or charge related inhibition 
of tissue penetration and reduce the potential for subsequent degradation.

\section{Glycoengineering and hyperglycosylation analogs of rHuEPO}

Glycoengineering is the process whereby new N-linked glycosylation consensus sequences are introduced into desirable positions in the peptide backbone in order to generate proteins with increased sialic acid containing carbohydrate to increase the serum half-life of the protein and thus the therapeutic activity in vivo. ${ }^{62}$ As described above, rHuEPO contains three naturally occurring $\mathrm{N}$-lined glycosylation sites and a single O-linked glycosylation site. The N-linked glycosylation sites have a tetraantenary structure and can contain up to a maximum of four terminal sialic acids whereas the O-linked sites have a bi-anterary structure and contain a maximum of two terminal sialic acids. ${ }^{63} \mathrm{~N}$-linked glycosylation initiates with the transfer of a 14-oligosaccharide precursor to the asparagine (Asn) located within the Asn-XSerine (Ser)/Threonine (Thr) consensus motif where $\mathrm{X}$ is any amino acid except Proline (Pro). ${ }^{64}$ This consensus sequence is known as the glycosylation sequon. The oligosaccharide undergoes maturation via the action of glycosyltransferases that append additional sugar units to the terminal mannose residues. ${ }^{65}$ Glycosylation sequons are necessary but not sufficient for N-linked carbohydrate addition to secreted proteins. ${ }^{66-68}$ Alteration of the adjacent sequences can convert non-functional glycosylation sequons to functional sites, indicating sequence context and/or secondary structure influence glycosylation. Secondary structures required for carbohydrate addition within functional glycosylation sequons are $\beta$ or Asn-X turns. ${ }^{69}$ As glycosylation is initiated prior to protein folding, sites normally buried within the molecule can be glycosylated. However, the resultant proteins may have altered protein structures and/or stabilities due to inhibition of correct protein folding as was observed for some rHuEPO analogs. ${ }^{62,68}$

In contrast, O-linked glycosylation is initiated by the attachment of a single monosaccharide, usually $\mathrm{N}$-acetylgalactosamine, to a Ser or Thr residue. ${ }^{70}$ The sugar is subsequently modified by glycosyltransferases to form a mature O-glycan structure. It is unknown why certain amino acid residues in a protein are selected for O-linked glycan addition as there is no clear consensus sequence for $\mathrm{O}$-linked glycosylation which may instead be defined by secondary structure. $^{71}$
The discovery that sialic acid containing carbohydrate was directly proportional to the serum half-life of rHuEPO and in vivo bioactivity led to the hypothesis that additional carbohydrates on the rHuEPO backbone could further enhance pharmacokinetic (PK) and in vivo activity and reduce dosing frequency. ${ }^{72}$ Therefore, the approach of introducing additional $\mathrm{N}$-linked glycosylation sites in $\mathrm{rHuEPO}$ to generate molecules with extended half-lives and enhanced biological and clinical activity was investigated and is described below.

\section{Darbepoetin alfa}

Darbepoetin alfa is a hyperglycosylated analogue of rHuEPO, has been approved for the treatment of anemia associated with chronic renal insufficiency and anemia associated with concomitant administered myelosuppressive chemotherapy, and has been used in the clinic for approximately 11 years. Darbepoetin alfa was created based on studies performed to investigate whether the introduction of additional N-linked glycosylation sequons into the rHuEPO peptide sequence could result in molecules with increased glycosylation and sialic acid content and thereby potentially increase the serum half-life and in vivo potency of the molecule. ${ }^{62} \mathrm{~N}$-linked glycosylation sequons were introduced into multiple sites within the rHuEPO molecule and the combination of sites at $\mathrm{Asn}^{30} \mathrm{Thr}^{32}$ and Valine (Val) ${ }^{87} \mathrm{Asn}^{88} \mathrm{Thr}^{90}$ resulted in the generation of a hyperglycosylated $\mathrm{rHuEPO}$ analog with two additional N-linked glycosylation sites, resulting in a total of five N-linked sites. ${ }^{62}$ Darbepoetin alfa was found to be efficiently glycosylated, maintained excellent molecular stability, and had a similar structural conformation to rHuEPO. The additional N-linked glycosylation sites increased the molecular weight of the molecule from $30.4 \mathrm{kDa}$ to $37.1 \mathrm{kDa}$ and changed the maximum number of sialic acids from 14 to 22 . As a consequence, carbohydrate content was increased from $40 \%$ to $51 \%$. The new carbohydrates were found to be processed in a manner similar to carbohydrates attached to the naturally occurring glycosylation sites and contained no new carbohydrate structures. ${ }^{62}$

When the in vitro bioactivity of darbepoetin alfa was investigated the kinetics and magnitude of EPOR mediated intracellular signaling was similar to rHuEPO, indicating that the additional carbohydrate did not blunt the maximum biological response. ${ }^{73}$ However, a slight shift in potency in vitro was observed which correlated with a slightly reduced affinity for EPOR (Figure 2). ${ }^{73}$ Studies in normal mice were performed to compare the erythropoietic potencies 
of darbepoetin alfa with that of rHuEPO. In order to elicit a similar erythropoietic response in mice, 3-fold more $\mathrm{rHuEPO}$ than darbepoetin alfa was required when dosed at three times per week. ${ }^{74}$ When weekly dosing paradigms were investigated, 13 fold more rHuEPO was required than darbepoetin alfa for a similar erythropoietic response which increased to approximately $30-40$ fold when examined as a single dose. ${ }^{75}$ Thus the relative in vivo potency of darbepoetin alfa compared to rHuEPO increased as the dosing interval increased. ${ }^{75}$ Comparative studies were also performed in rodent disease models. In a model of chemotherapy/radiotherapy induced anemia, a 6-fold higher dose of rHuEPO was less effective at stimulating erythropoiesis than darbepoetin alfa. ${ }^{58}$ Darbepoetin alfa was also found to be effective in treating anemia in a rat model of anemia of inflammation. ${ }^{76}$ These preclinical studies demonstrated that the further addition of N-linked glycosylation sites could directly increase the in vivo potency of rHuEPO and that darbepoetin alfa was effective in animal models of anemia.

To understand the increase in potency of the $\mathrm{rHuEPO}$ analogs, preclinical PK studies were performed. The enhanced glycosylation of darbepoetin alfa was found to increase the serum half-life by 3 -fold in rats and dogs when compared to rHuEPO. ${ }^{74}$ In clinical studies, darbepoetin alfa had an approximately 3 -fold longer mean terminal halflife than $\mathrm{rHuEPO}$ in patients receiving peritoneal dialysis, with more than a 2-fold greater area under the curve and a 2.5 -fold reduced clearance. ${ }^{77}$ In these patients, the mean half-life of darbepoetin alfa was also found to increase approximately 2-fold when administered subcutaneously compared to intravenous administration. ${ }^{77}$ Darbepoetin alfa was also found to have an increased serum half-life in anemic patients with nonmyeloid malignancies receiving multiple cycles of chemotherapy when compared with rHuEPO. ${ }^{59}$ In patients with chemotherapy-induced anemia, this half-life was estimated to be 61-88 hours, depending on timing of chemotherapy. ${ }^{59}$
One theoretical drawback to the glycoengineering of therapeutic proteins could be immune recognition of the mutated amino acid sequence resulting in the production of neutralizing antibodies. Darbepoetin alfa differs from rHuEPO at five amino acid positions suggesting that an antibody could theoretically be directed against the "altered" region. However, antibody formation was monitored during clinical trials with darbepoetin alfa and no enhanced formation of neutralizing antibodies was observed when compared to epoetin alfa made in the US. ${ }^{78}$ Indeed, carbohydrates and sialic acid on darbepoetin alfa inhibited antibody binding in immunoassays compared with deglycosylated and desialated molecules. ${ }^{79}$

\section{AMG II 4 and AMG 205}

Hyperglycosylated analogs of rHuEPO have also been evaluated to determine if further increasing the number of N-linked carbohydrate sites above darbepoetin alfa would further increase the half-life and in vivo potency of the ESA. Analogue AMG 205 was initially generated and contained four additional $\mathrm{N}$-linked glycosylation sites compared to rHuEPO, for a total of seven. ${ }^{80}$ The increase in glycosylation from two additional sites in darbepoetin alfa to four additional sites in AMG 205, decreased receptor affinity and in vitro biological activity (Table 1 and Figure 2) but increased the serum half-life in rats from 17.2 hours to 31 hours when administered intravenously and 13.2 hours to 28.2 when administered subcutaneously. ${ }^{80}$ Though the molecular stability of AMG 205 was suitable based on antibody binding assays to an internal epitope recognized by the 9G8a antibody, the O-linked site was not efficiently glycosylated and development of this molecule was discontinued. ${ }^{80}$

Another hyperglycosylated analog AMG 114, also contained four additional N-linked glycosylation sites but was efficiently glycosylated at the O-linked site and also maintained excellent stability as determined by the 9G8a antibody binding assay. ${ }^{80}$ This molecule therefore

Table I Summary table of the in vitro proliferation $\mathrm{EC}_{50}$ values and the $\mathrm{IC}_{50}$ receptor binding activity in rHuEPO competition assays using UT-7/EPO cells

\begin{tabular}{llll}
\hline Sample & $\begin{array}{l}\text { \# of } \mathbf{N} \text {-linked } \\
\text { carbohydrates }\end{array}$ & $\begin{array}{l}\text { In vitro proliferation } \\
\left.\text { activity (mean } \mathbf{E C}_{50}, \mathbf{p M}\right)\end{array}$ & $\begin{array}{l}\text { In vitro receptor binding } \\
\text { activity (mean IC }\end{array}$ \\
\hline rHuEPO & pM)
\end{tabular}

Notes: An inverse correlation was observed with increasing number of $\mathrm{N}$-linked carbohydrate and decreased in vitro proliferation activity and receptor binding activity. Values are means of two independent experiments. Data kindly provided by Steve Elliott, Norma Rogers, and Tony Lorenzini, Amgen, Inc.

Abbreviations: $\mathrm{EC}_{50}, 50 \%$ effective concentration; $\mathrm{IC}_{50}, 50 \%$ inhibitory concentration; EPO, erythropoietin; rHuEPO, recombinant human EPO. 
contained a maximum of 30 sialic acids. The inclusion of four additional N-linked carbohydrates increased the molecule weight from $30.4 \mathrm{kDa}$ in rHuEPO to $44.8 \mathrm{kDa}$ in AMG 114. Molecular structural analyses identified that the additional carbohydrates were distal to the receptor binding sites thus retaining receptor binding activity ${ }^{80}$ though $\mathrm{AMG}$ 114 also had reduced in vitro activity and receptor affinity compared with rHuEPO and darbepoetin alfa (Table 1 and Figure 2). In dog PK studies, AMG 114 had a serum halflife of 68.9 hours compared to 20.4 hours of darbepoetin alfa. Furthermore, in clinical trials in chemotherapy induced anemia patients, AMG 114 was found to have a serum halflife of approximately 130 hours compared to 73.7 hours with darbepoetin alfa ${ }^{81}$ Dose dependent increases in hemoglobin were observed though modest, and the molecule appeared to be well tolerated. ${ }^{81}$ However, AMG 114 was not further developed as darbepoetin alfa was found to meet the existing clinical needs with a synchronous chemotherapy administration schedule. ${ }^{81}$

\section{Pegylation of rHuEPO}

Several approaches have been taken to generate ESAs with enhanced serum half-life and in vivo bioactivity through the synthetic chemical addition of polyethylene glycol to fully glycosylated rHuEPO.

\section{Pegzyrepoetin alfa}

Recently, a molecule consisting of a pegylated and fully glycosylated rHuEPO was approved for the treatment of anemia associated with chronic kidney disease (CKD) in several countries. Pegzyrepoetin alfa has been reported to be generated by the addition of methoxy-polyethylene glycol (PEG) polymer chain to the rHuEPO N-terminal amino acid or the $\varepsilon$-amino group on lysines 45 or 52 with a single succinimidyl butanoic acid linker. ${ }^{82}$ The PEG used in the conjugation to fully glycosylated rHuEPO is a $30 \mathrm{kDa}$ chain polymer and increases the molecular weight of the molecule to approximately $60 \mathrm{kDa}$. In preclinical studies, though rHuEPO was more potent than pegzyrepoetin alfa in the induction of cellular proliferation in an EPO dependent cell line UT-7/EPO in vitro, pegzyrepoetin alfa was able to increase reticulocyte count more effectively than identical peptide amounts of rHuEPO in normal mice. ${ }^{83} \mathrm{In}$ these studies, a single injection of $20 \mu \mathrm{g} / \mathrm{kg}$ of pegzyrepoetin alfa in mice was reported to increase reticulocyte count by $13 \%$ vs $7.8 \%$ with a comparable peptide dose of rHuEPO. ${ }^{84}$ In humans, the PK has been investigated and the serum half-life via both intravenously and subcutaneous administration was approximately 130 hours. ${ }^{85}$ In clinical efficacy studies, pegzyrepoetin alfa has been suggested to produce stable hemoglobin levels in CKD patients with once monthly administration. ${ }^{86}$ It is currently unclear how pegzyrepoetin alfa is cleared and the mechanisms that account for the enhanced in vivo activity. As with other PEGylated molecules (eg, pegfilgrastim), the attachment of a highly hydrophilic PEG molecule increases the molecular size and therefore reduces renal clearance and extends serum half-life. ${ }^{87}$ However, the pegylation may interfere with receptor binding due to steric hindrance and indeed pegzyrepoetin alfa has been reported to have a lower receptor affinity for EPOR. ${ }^{88}$

Recently, a study in sheep to evaluate PK and receptor interactions of $\mathrm{rHuEPO}$ and pegzyrepoetin alfa reported pegzyrepoetin alfa was less able to induce EPOR expression in the erythroid compartment in vivo, had slower binding to EPOR and had a reduced internalization and subsequent degradation of surface bound pegzyrepoetin alfa ${ }^{89}$ However, the mechanism for improved half-life and reduced clearance need further elucidation.

\section{MK-2578}

Another pegylated version of glycosylated rHuEPO, MK-2578, was reported to have reached the clinical development stage. In contrast to Chinese Hamster Ovary synthesis of rHuEPO, the glycosylated rHuEPO in MK-2578 was reported to be synthesized in yeast. ${ }^{90}$ Yeast Pichia pastoris were genetically engineered to secrete human glycoproteins with fully complex terminally sialylated N-glycans. ${ }^{91}$ The yeast cell lines were reported to produce complex glycoproteins with greater than $90 \%$ terminal sialylation and were used to synthesize functional $\mathrm{rHuEPO}$ that dose dependently increased hematocrit in mice. ${ }^{91}$ Though MK-2578 was in clinical development for the treatment of anemia associated with chronic renal insufficiency, this drug was reportedly halted in Phase II trials in 2010 due to an US Food and Drug Administration (FDA) request for cardiovascular outcomes in clinical trials. ${ }^{92}$

\section{EPO mimetic proteins}

The potential for EPO mimetic proteins to bind, dimerize, and activate the EPOR have been investigated as new modalities to generate ESAs. Several approaches have been taken to evaluate the erythropoietic activity of these agents and improve their half-life and in vivo potency through identification of EPO mimetic peptides (EMP), dimerization of EMPs though covalent chemical approaches and pegylation, 
conjugation of EMPs to antibody Fc regions, and generation of agonistic anti-EPOR antibodies.

\section{EMPI}

Approaches to identify EMP sequences initially used a filamentous phage display library to screen binding phage to the extracellular domain of human EPOR. A 14-mer cyclic peptide with internal disulphide bonds, AF11154, was identified that was able to bind and displace radioactive rHuEPO binding to EPOR, though at a low potency of $10 \mu \mathrm{M} \mathrm{IC}{ }_{50}{ }^{93}$ Subsequent screening of mutated peptides derived from AF11154 identified peptides including EMP1 that were able to displace radioactive $\mathrm{rHuEPO}$ binding with a $50 \%$ inhibitory concentration $\left(\mathrm{IC}_{50}\right)$ of $0.3 \mu \mathrm{M} .{ }^{93} \mathrm{EMP} 1$ was found to have in vitro bioactivity using EPOR expressing cell line proliferation assays and in vitro erythroid colony formation potential from human bone marrow though the potency was $\sim 9,000$-fold and $\sim 40,000$-fold less potent than rHuEPO in these assays, respectively. ${ }^{93}$ The low potency of the EMP1 molecule in vitro also translated to erythropoietic assays in vivo with approximately a 650,000 fold reduced in vivo activity of EMP1 compared to $\mathrm{rHEPO}$ when compared on a molar basis. ${ }^{93,94}$ Pegylated versions of EMP1 dimers were also generated through the addition of the PEG molecules to the N-terminal amino acids of the peptides. This modification increased the potency of the molecule $\sim 50$-fold in vitro and $\sim 14$-fold in vivo. ${ }^{94}$ Chemical covalent dimerization of the EMP1 peptide was also performed and this was found to increase the potency of the chemical-EMP1 dimer $\sim 100$-fold versus the native peptide using in vitro and in vivo assays. ${ }^{94,95}$ However, this chemical EMP1 dimer was still reported to be $\sim 6,000$-fold less potent than $\mathrm{rHuEPO}$ on a molar basis using in vivo erythropoietic assays..$^{94,95}$

\section{CNTO 528 and CNTO 530}

Two approaches using the EMP1 peptide as the EPOR binding domain but fused to Fc proteins have been described to attempt to create an EPOR agonist therapeutic with an extended serum half-life and in vivo biological activity. CNTO 528 has been described to be a fusion protein of EMP1 with the Fc region of human IgG1. In a phase I clinical trial in adult healthy volunteers, CNTO 528 was reported to be well tolerated and effective at raising and maintaining hemoglobin levels by at least $1 \mathrm{~g} / \mathrm{dL}$ following a single intravenous administration. ${ }^{96}$ After a single intravenous administration of CNTO 528, the serum half-life was reported to range from 1.55 to 7.6 days at doses between 0.03 and $0.9 \mathrm{mg} / \mathrm{kg} .{ }^{96} \mathrm{CNTO} 530$ is a $58 \mathrm{kDa}$ glycoprotein with two EMP-1 sequences as a pharmacophore ${ }^{97}$ and is fused to the human IgG4 Fc domain. ${ }^{97}$ Preclinical studies reported the CNTO 530 competitively bound to the EPOR in UT-7/EPO cells with an $\mathrm{IC}_{50}$ of $17 \mathrm{pM}$ and induced EPOR dependent signaling in the same cell line. ${ }^{97}$ In pharmacokinetic studies in mice the half life $\left(\mathrm{T}_{1 / 2}\right)$ was $\sim 40$ hours and a single dose of $0.3 \mathrm{mg} / \mathrm{kg}$ significantly increased erythropoietic parameters (hemoglobin and RBC) that were maintained for $\sim 28$ days. More recent studies have reported that CNTO 530 can treat chemotherapy induced anemia in mouse models with 5-fluorouracil or carboplatin plus paclitaxel. ${ }^{98}$ These studies have also suggested that CNTO 530 can provide a sustained activation of ribosomal S6 kinases p70S6K (presumably downstream of EPOR) that was not seen with rHuEPO or darbepoetin alfa, and can also provide an enhanced expansion of bone marrow resident erythroid progenitor pool, though it is unclear how this may occur mechanistically. ${ }^{98}$ The clinical utility of this molecule is however yet to be investigated.

\section{Peginesatide}

Peginesatide is also a pegylated EMP and recently completed Phase III clinical trials that evaluated the potential of the molecule to treat anemia in patients with chronic renal failure. The preclinical properties of peginesatide have been evaluated and have been reported to compete with native rHuEPO for EPOR binding and displace radioactive EPO from the EPOR with an $\mathrm{IC}_{50} \sim 37 \mathrm{pM}$ versus $7 \mathrm{pM}$ for rHuEPO. ${ }^{99}$ Peginesatide was also reported to induce downstream EPOR signaling through JAK2, STAT5, and AKT in an EPO dependent cell line UT-7/EPO, and induced cellular proliferation in vitro at an $\mathrm{EC}_{50}$ of 460 pM versus 36 pM rHuEPO. ${ }^{99}$ The potential of peginesatide to induce human erythroid colony formation was also evaluated in vitro and was found to be $\sim 16$-fold less potent than $\mathrm{rHuEPO}$ on a molar basis..$^{99}$ In preclinical pharmacokinetic studies, after a single bolus injection of peginesatide, the $\mathrm{T}_{1 / 2}$ was reported to be $\sim 22-31$ hours in rats and 14-59 hours in monkeys, depending on the dose used ${ }^{99}$ with renal elimination as one of the routes of clearance. The potential for peginesatide to enhance erythropoiesis was evaluated in vivo by examining the elevation of reticulocytes and hemoglobin after single intravenous doses between 0.1 and $10 \mathrm{mg} / \mathrm{kg}$ in rats and monkeys. In these studies, peginesatide dose dependently increased reticulocytes and hemoglobin..$^{99}$ In healthy volunteers, the half-life of peginesatide has been reported to be 19-30 hours when administered intravenously and 35-68 hours when administered by a subcutaneous route, whereas in CKD patients the half-life has been reported to be 41 hours. ${ }^{100}$ In both Phase II and Phase III studies, peginesatide was reported to treat anemia in patients with chronic renal failure. ${ }^{100-102}$ Based on these studies a new drug 
application was filed in the USA in May 2011 for the treatment of anemic chronic renal insufficient patients on dialysis and was approved in March 2012. However, an increase in cardiovascular events was observed in CKD patients not on dialysis treated with peginesatide and was not approved for that indication. ${ }^{103}$ In addition, due to recent reports of severe allergic reactions including some deaths, the drug was voluntarily recalled in February 2013 and an investigation is ongoing to understand the nature of the adverse reactions to the drug.

One potential theoretical advantage of having a molecule that is immunologically distinct from EPO is that neutralizing antibodies potentially generated to peginesatide in patients would not interact with endogenous EPO, therefore potentially preventing PRCA. This concept was explored in a rat model of PRCA and it was reported that rat anti-EPO antibodies did not cross react with peginesatide and the anemia induced could be treated in the rats. ${ }^{104}$ In a clinical study, CKD patients with PRCA were treated with peginesatide and in some patients reticulocytes increased, along with an increase in hemoglobin and decrease in transfusion dependence. ${ }^{105}$ However, in this study one patient that had initially responded subsequently developed neutralizing antibodies to peginesatide and became transfusion dependent again. ${ }^{105}$

\section{Anti-EPOR agonistic antibodies}

Due to the general long in vivo half-life of antibodies, several different approaches have been taken to generate agonistic anti-EPOR antibodies that may provide extended erythropoiesis with less frequent dosing than rHuEPO. The first reported description of agonistic anti-EPO antibodies was by Elliott et al $1996^{106}$ who generated mouse monoclonal antibodies to the human extracellular region of EPOR. Several of the bivalent antibodies were able to compete with the binding of radioactive EPO to erythroleukemic cell lines, were able to induce the proliferation of EPO dependent UT-7/EPO cells and were able to promote the differentiation of human CD34+ hematopoietic progenitors to erythroid colonies. ${ }^{106}$ However, the most potent monoclonal antibody $(\mathrm{mAb}) \mathrm{mAb} 71$ was 2-3 log fold less potent than $\mathrm{rHuEPO}$ in proliferation assays and 5-6 log fold less potent in the erythroid colony forming assays. However, monovalent Fab fragments of mAb 71 failed to activate the receptor as EPOR requires dimerization and subsequent conformational change to occur for functional activation of signaling. Similar low potency in vitro activity was reported with another anti-EPOR mouse monoclonal antibody. ${ }^{107}$ Recently a fully human agonistic anti-EPOR antibody ABT007 was reported to have been generated using the XenoMouse technology. ${ }^{108}$ Using in vitro studies, ABT007 was 10-fold less potent using in vitro cell line proliferation assays and 5-40 more ABT007 was needed than rHuEPO to reach a maximum erythroid colony formation from human bone marrow CD34+ hematopoietic progenitors. However, using in vivo studies ABT007 increased hematocrit with once monthly dosing and was reported to be comparable to darbepoetin alfa dosed every 2 weeks in mice. ${ }^{108} \mathrm{As}$ the antibody was reported not to bind to mouse EPOR, the investigators had to use mice with the humanized EPOR to perform their studies. Interestingly, analysis of the antibodies from these studies found that in vitro and in vivo potency correlated inversely with binding affinity. ${ }^{109}$ The development status of ABT007 is at this point unknown.

Recently an approach to generate heterodimeric bispecific antibodies using combinatorial antibody libraries has been investigated which identified bi-specific antibodies that asymmetrically bind to EPOR to activate JAK/STAT5 pathways and generate hemoglobinized erythroid colonies from human CD34+ progenitors. ${ }^{110}$ However, these prototype molecules are still $\sim 5$-fold less potent than $\mathrm{rHuEPO}$ in vitro assays and the in vivo potency at this time is unknown.

\section{Other approaches}

Several other approaches have been taken to develop ESAs with improved serum half-lives and in vivo erythropoietic activity. In one study, investigators cross-linked cysteine residues in rHuEPO monomers to form $\mathrm{rHuEPO}$ dimers and trimers using a chemical modification process. ${ }^{111}$ In these studies, the investigators reported that the chemically induced rHuEPO dimers had an extended plasma half-life in comparison with rHuEPO monomers ( $>24$ hours versus 4 hours) in intravenous-injected rabbits, and correlated with an enhanced ability to increase hematocrit in mice ( $\sim 56 \%$ versus $\sim 51 \%)$. In a similar study by the same group, the investigators synthesized recombinant rHuEPO dimers joined by a 17 amino acid flexible peptide in COS cells, an African green monkey cell line. ${ }^{112}$ Using an in vitro bioassay, the rHuEPO dimers were reported to have an 5-6-fold increase in specific activity when compared on a molar basis and were reported to have an improved serum half-life and elevated hematocrit above that of rHuEPO alone after a single intravenous dose. ${ }^{112}$

rHuEPO has also been fused to the human neonatal antibody FcRn region of IgG1 to extend the serum half-life and also provide a transport mechanism across pulmonary epithelium as an alternative delivery route. ${ }^{113}$ Several molecules were tested including a construct containing two EPO molecules fused to two chains of the FcRn and a chimeric 


\section{Approved}

Epoetin alfa (rHuEPO)

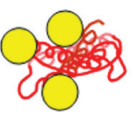

Darbepoetin alfa

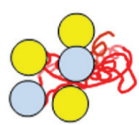

Pegzyrpoetin alfa

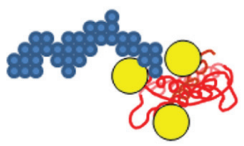

Peginesatide*

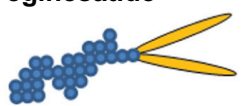

Erythroid progenitor

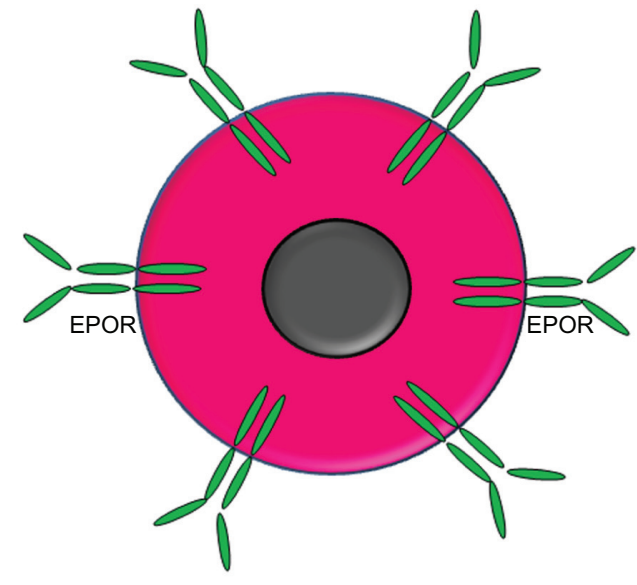

Experimental

AMG 114
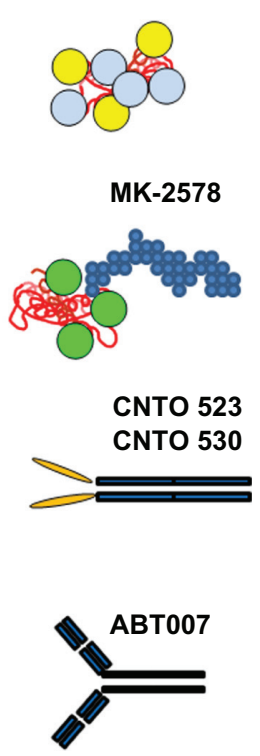

Figure 3 Schematic representation of approved and experimental ESA molecules.

Notes: Shown are schematic diagrams of the molecular structures: red molecule, EPO-based peptide; yellow circles, carbohydrate attached to naturally occurring N-linked glycosylation sites; light blue circles, carbohydrate attached to engineered $\mathrm{N}$-linked glycosylation sites; green circles; carbohydrate generated in yeast at naturally occurring $\mathrm{N}$-linked glycosylation sites; small blue circles, PEG; orange ovals, EPO mimetic peptides; dark blue rectangles, antibodies or Fc portion of antibody. An erythroid progenitor with surface EPOR is also shown. *As of February 20I3, peginesatide is no longer on the market.

Abbreviations: EPO, erythropoietin; EPOR, EPO receptor; ESA, erythropoiesis stimulating agent; PEG, methoxy-polyethylene glycol; rHuEPO, recombinant human EPO.

molecule containing only a single EPO attached to the FcRn dimer. In studies using non-human primates and using an aerosol method of delivery to the lung epithelium, the EPO$\mathrm{Fc}$ monomer more improved $\mathrm{PK}$ properties and in vivo erythropoietic responses than the EPO-Fc dimer. ${ }^{113}$ In a phase I clinical trial in normal healthy volunteers, the investigators reported that aerosolized EPO-Fc was able to be delivered by inhalation with dose dependent increases in PK and pharmacodynamic effects. ${ }^{114}$ However the current development status of this molecule is unknown.

\section{Conclusions}

ESAs have been used successfully to treat anemia in millions of patients, reducing the number of transfusions required. Since the discovery that $\mathrm{rHuEPO}$ could effectively increase hemoglobin levels in patients and reduce the numbers of transfusions, alternative approaches have been taken to improve upon the PK and pharmacodynamic properties of new therapeutic molecules. These approaches have included the glycoengineering and PEGylation of rHuEPO and the identification of EPO mimetic proteins conjugated to PEG or fused to antibody Fc regions (Figure 3). In general, these new ESAs share many similarities: the molecules activate the EPOR in the same way and the enhanced erythropoietic activity of the molecules in vivo correlate with extended serum half-life, but the enhanced in vivo activity is inversely related to the in vitro activity and receptor affinity. It will be interesting to determine if newly developed ESAs have the same general properties of existing ESAs or whether alternative approaches to synergize with other mechanisms/ receptors to enhance erythropoiesis are efficacious and are developed clinically.

\section{Acknowledgments}

The author would like to thank William Stark, Shawn Lee, Steve Elliott, Jonathan Baxter and Barbra Sasu for critically reviewing and editing the manuscript.

\section{Disclosure}

AMS (author), WS, SL, and BS (see acknowledgments) are employees of Amgen, Inc and hold stock. SE is a consultant for Amgen, Inc and holds stock. JB holds Amgen, Inc stock. The author has no other disclosures to declare.

\section{References}

1. Aapro M. Emerging topics in anaemia and cancer. Ann Oncol. 2012; 23 Suppl 10:x289-x293.

2. Elliott S, Sinclair AM. The effect of erythropoietin on normal and neoplastic cells. Biologics. 2012;6:163-189. 
3. Molineux G, Sinclair A. Biology of erythropoietin. In: Parnham MJ, Bruinvels J, editors. Erythropoietins, Erythropoietic Factors, and Erythropoiesis, 2nd ed. Basel: Birkhauser; 2009:41-60.

4. Muchnik E, Kaplan J. HIF prolyl hydroxylase inhibitors for anemia. Expert Opin Investig Drugs. 2011;20(5):645-656.

5. Constantinescu SN, Keren T, Socolovsky M, Nam H, Henis YI, Lodish HF. Ligand-independent oligomerization of cell-surface erythropoietin receptor is mediated by the transmembrane domain. Proc Natl Acad Sci US A. 2001;98(8):4379-4384.

6. Philo JS, Aoki KH, Arakawa T, Narhi LO, Wen J. Dimerization of the extracellular domain of the erythropoietin (EPO) receptor by EPO: one high-affinity and one low-affinity interaction. Biochemistry. 1996;6(35): 1681-1691.

7. Supino-Rosin L, Yoshimura A, Altaratz H, Neumann D. A cytosolic domain of the erythropoietin receptor contributes to endoplasmic reticulumassociated degradation. Eur J Biochem. 1999;263(2):410-419.

8. Hilton DJ, Watowich SS, Murray PJ, Lodish HF. Increased cell surface expression and enhanced folding in the endoplasmic reticulum of a mutant erythropoietin receptor. Proc Natl Acad Sci U S A. 1995;92(1): 190-194.

9. Neumann D, Wikstrom L, Watowich SS, Lodish HF. Intermediates in degradation of the erythropoietin receptor accumulate and are degraded in lysosomes. J Biol Chem. 1993;268(18):13639-13649.

10. Meyer L, Deau B, Forejtnikova H, et al. beta-Trcp mediates ubiquitination and degradation of the erythropoietin receptor and controls cell proliferation. Blood. 2007;109(12):5215-5222.

11. Walrafen P, Verdier F, Kadri Z, Chretien S, Lacombe C, Mayeux P. Both proteasomes and lysosomes degrade the activated erythropoietin receptor. Blood. 2005;105(2):600-608.

12. Huang LJ, Constantinescu SN, Lodish HF. The N-terminal domain of Janus kinase 2 is required for Golgi processing and cell surface expression of erythropoietin receptor. Mol Cell. 2001;8(6):1327-1338.

13. Seubert N, Royer Y, Staerk J, et al. Active and inactive orientations of the transmembrane and cytosolic domains of the erythropoietin receptor dimer. Mol Cell. 2003;12(5):1239-1250.

14. Wojchowski DM, Gregory RC, Miller CP, Pandit AK, Pircher TJ. Signal transduction in the erythropoietin receptor system. Exp Cell Res. 1999;253(1):143-156.

15. Wojchowski DM, Sathyanarayana P, Dev A. Erythropoietin receptor response circuits. Curr Opin Hematol. 2010;17(3):169-176.

16. Minoo P, Zadeh MM, Rottapel R, Lebrun JJ, Ali S. A novel SHP-1/ Grb2-dependent mechanism of negative regulation of cytokine-receptor signaling: contribution of SHP-1 C-terminal tyrosines in cytokine signaling. Blood. 2004;103(4):1398-1407.

17. Jegalian AG, Wu H. Differential roles of SOCS family members in EpoR signal transduction. J Interferon Cytokine Res. 2002;22(8):853-860.

18. de la Chapelle A, Traskelin AL, Juvonen E. Truncated erythropoietin receptor causes dominantly inherited benign human erythrocytosis. Proc Natl Acad Sci U S A. 1993;90(10):4495-4499.

19. Arcasoy MO, Karayal AF, Segal HM, Sinning JG, Forget BG. A novel mutation in the erythropoietin receptor gene is associated with familial erythrocytosis. Blood. 2002a;99(8):3066-3069.

20. Jacobs K, Shoemaker C, Rudersdorf R, et al. Isolation and characterization of genomic and cDNA clones of human erythropoietin. Nature. 1985;313(6005):806-810.

21. Lin FK, Suggs S, Lin CH, et al. Cloning and expression of the human erythropoietin gene. Proc Natl Acad Sci U S A. 1985;82(22): 7580-7584.

22. Davis JM, Arakawa T, Strickland TW, Yphantis DA. Characterization of recombinant human erythropoietin produced in Chinese hamster ovary cells. Biochemistry. 1987;26(9):2633-2638.

23. Browne JK, Cohen AM, Egrie JC, et al. Erythropoietin: gene cloning, protein structure, and biological properties. Cold Spring Harb Symp Quant Biol. 1986;51 Pt 1:693-702.

24. Egrie JC, Browne J, Lai P, Lin FK. Characterization of recombinant monkey and human erythropoietin. Prog Clin Biol Res. 1985;191: 339-350.
25. Rudd PM, Dwek RA. Glycosylation: heterogeneity and the 3D structure of proteins. Crit Rev Biochem Mol Biol. 1997;32(1):1-100.

26. Sasaki H, Bothner B, Dell A, Fukuda M. Carbohydrate structure of erythropoietin expressed in Chinese hamster ovary cells by a human erythropoietin cDNA. J Biol Chem. 1987;262(25):12059-12076.

27. Rush RS, Derby PL, Smith DM, et al. Microheterogeneity of erythropoietin carbohydrate structure. Anal Chem. 1995;67(8):1442-1452.

28. Kiss Z, Elliott S, Jedynasty K, Tesar V, Szegedi J. Discovery and basic pharmacology of erythropoiesis-stimulating agents (ESAs), including the hyperglycosylated ESA, darbepoetin alfa: an update of the rationale and clinical impact. Eur J Clin Pharmacol. 2010;66(4): 331-340.

29. Tsuda E, Kawanishi G, Ueda M, Masuda S, Sasaki R. The role of carbohydrate in recombinant human erythropoietin. Eur J Biochem. 1990;188(2):405-411.

30. Narhi LO, Arakawa T, Aoki KH, et al. The effect of carbohydrate on the structure and stability of erythropoietin. J Biol Chem. 1991;266(34): 23022-23026.

31. Endo Y, Nagai H, Watanabe Y, Ochi K, Takagi T. Heat-induced aggregation of recombinant erythropoietin in the intact and deglycosylated states as monitored by gel permeation chromatography combined with a low-angle laser light scattering technique. J Biochem. 1992;112(5):700-706.

32. Uchida E, Morimoto K, Kawasaki N, Izaki Y, Abdu Said A, Hayakawa T. Effect of active oxygen radicals on protein and carbohydrate moieties of recombinant human erythropoietin. Free Radic Res. 1997;27(3): 311-323.

33. Goochee CF, Gramer M, Andersen D, Bahr J, Rasmussen JR. The oligosaccharides of glycoproteins: factors affecting their synthesis and their influence on glycoprotein properties. In: Sikdar SK, Brier M, Todd P, editors. Frontiers in Bioprocessing II. Washington: American Chemical Society; 1991:199-240.

34. Stowers AW, Chen Lh LH, Zhang Y, et al. A recombinant vaccine expressed in the milk of transgenic mice protects Aotus monkeys from a lethal challenge with Plasmodium falciparum. Proc Natl Acad Sci USA. 2002;99(1):339-344.

35. Casadevall N, Nataf J, Viron B, et al. Pure red-cell aplasia and antierythropoietin antibodies in patients treated with recombinant erythropoietin. N Engl J Med. 2002;346(7):469-475.

36. Bennett CL, Luminari S, Nissenson AR, et al. Pure red-cell aplasia and epoetin therapy. N Engl J Med. 2004;351(14):1403-1408.

37. Schellekens H, Jiskoot W. Eprex-associated pure red cell aplasia and leachates. Nat Biotechnol. 2006;24(6):613-614.

38. Imperiali B, O'Connor SE. Effect of N-linked glycosylation on glycopeptide and glycoprotein structure. Curr Opin Chem Biol. 1999;3(6): 643-649.

39. Elliott S, Chang D, Delorme E, et al. Isolation and characterization of conformation sensitive antierythropoietin monoclonal antibodies: effect of disulfide bonds and carbohydrate on recombinant human erythropoietin structure. Blood. 1996;87(7):2714-2722.

40. Fernandes AI, Gregoriadis G. The effect of polysialylation on the immunogenicity and antigenicity of asparaginase: implication in its pharmacokinetics. Int J Pharm. 2001;217(1-2):215-224.

41. Ho CL, Lin YL, Chen WC, Rocchi R, Piek T. Comparison of the immunogenicity of wasp venom peptides with or without carbohydrate moieties. Toxicon. 1998;36(1):217-221

42. Egrie JC, Browne JK. Development and characterization of novel erythropoiesis stimulating protein (NESP). Br J Cancer. 2001; 84 Suppl 1:3-10.

43. Higuchi M, Oh-eda M, Kuboniwa H, Tomonoh K, Shimonaka Y, Ochi N. Role of sugar chains in the expression of the biological activity of human erythropoietin. J Biol Chem. 1992;267(11):7703-7709.

44. Fukuda MN, Sasaki H, Lopez L, Fukuda M. Survival of recombinant erythropoietin in the circulation: the role of carbohydrates. Blood. 1989;73(1):84-89.

45. Spivak JL, Hogans BB. The in vivo metabolism of recombinant human erythropoietin in the rat. Blood. 1989;73(1):90-99. 
46. Widness JA, Veng-Pedersen P, Schmidt RL, Lowe LS, Kisthard JA, Peters C. In vivo 125I-erythropoietin pharmacokinetics are unchanged after anesthesia, nephrectomy and hepatectomy in sheep. J Pharmacol Exp Ther. 1996;279(3):1205-1210.

47. Kindler J, Eckardt KU, Ehmer B, et al. Single-dose pharmacokinetics of recombinant human erythropoietin in patients with various degrees of renal failure. Nephrol Dial Transplant. 1989;4(5):345-349.

48. Macdougall IC, Roberts DE, Coles GA, Williams JD. Clinical pharmacokinetics of epoetin (recombinant human erythropoietin). Clin Pharmacokinet. 1991;20(2):99-113.

49. Jensen JD, Jensen LW, Madsen JK, Poulsen L. The metabolism of erythropoietin in liver cirrhosis patients compared with healthy volunteers. Eur J Haematol. 1995;54(2):111-116.

50. Dinkelaar RB, Engels EY, Hart AA, Schoemaker LP, Bosch E, Chamuleau RA. Metabolic studies on erythropoietin (EP): II. The role of liver and kidney in the metabolism of Ep. Exp Hematol. 1981; 9(7):796-803.

51. Clarenburg R. Asialoglycoprotein receptor is uninvolved in clearing intact glycoproteins from rat blood. Am J Physiol. 1983;244(3):G247-G253.

52. Ishibashi S, Hammer RE, Herz J. Asialoglycoprotein receptor deficiency in mice lacking the minor receptor subunit. J Biol Chem. 1994;269(45):27803-27806

53. Tozawa R, Ishibashi S, Osuga J, et al. Asialoglycoprotein receptor deficiency in mice lacking the major receptor subunit. Its obligate requirement for the stable expression of oligomeric receptor. $J$ Biol Chem. 2001;276(16):12624-12628.

54. Sawyer ST, Krantz SB, Goldwasser E. Binding and receptor-mediated endocytosis of erythropoietin in Friend virus-infected erythroid cells J Biol Chem. 1987;262(12):5554-5562.

55. Gross AW, Lodish HF. Cellular trafficking and degradation of erythropoietin and novel erythropoiesis stimulating protein (NESP). J Biol Chem. 2006;281(4):2024-2032.

56. Chapel S, Veng-Pedersen P, Hohl RJ, Schmidt RL, McGuire EM, Widness JA. Changes in erythropoietin pharmacokinetics following busulfan-induced bone marrow ablation in sheep: evidence for bone marrow as a major erythropoietin elimination pathway. J Pharmacol Exp Ther. 2001;298(2):820-824.

57. Veng-Pedersen P, Chapel S, Al-Huniti NH, et al. Pharmacokinetic tracer kinetics analysis of changes in erythropoietin receptor population in phlebotomy-induced anemia and bone marrow ablation. Biopharm Drug Dispos. 2004;25(4):149-156.

58. Hartley C, Elliott S, Begley CG, et al. Kinetics of haematopoietic recovery after dose-intensive chemo/radiotherapy in mice: optimized erythroid support with darbepoetin alpha. Br J Haematol. 2003;122(4): 623-636.

59. Glaspy J, Henry D, Patel R, et al. Effects of chemotherapy on endogenous erythropoietin levels and the pharmacokinetics and erythropoietic response of darbepoetin alfa: a randomised clinical trial of synchronous versus asynchronous dosing of darbepoetin alfa. Eur J Cancer. 2005;41(8):1140-1149.

60. Agoram B, Aoki K, Doshi S, et al. Investigation of the effects of altered receptor binding activity on the clearance of erythropoiesis-stimulating proteins: nonerythropoietin receptor-mediated pathways may play a major role. J Pharm Sci. 2009;98(6):2198-2211.

61. Flaharty KK. Clinical pharmacology of recombinant human erythropoietin (r-HuEPO). Pharmacotherapy. 1990;10(2(Pt 2)):9S-14S.

62. Elliott S, Lorenzini T, Asher S, et al. Enhancement of therapeutic protein in vivo activities through glycoengineering. Nat Biotechnol. 2003;21(4):414-421.

63. Sinclair AM, Elliott S. Glycoengineering: the effect of glycosylation on the properties of therapeutic proteins. J Pharm Sci. 2005;94(8): 1626-1635.

64. Bause E. Structural requirements of N-glycosylation of proteins. Studies with proline peptides as conformational probes. Biochem J. 1983;209(2):331-336.

65. Kornfeld R, Kornfeld S. Assembly of asparagine-linked oligosaccharides. Annu Rev Biochem. 1985;54:631-664.
66. Gavel Y, von Heijne G. Sequence differences between glycosylated and non-glycosylated Asn-X-Thr/Ser acceptor sites: implications for protein engineering. Protein Eng. 1990;3(5):433-442.

67. Apweiler R, Hermjakob H, Sharon N. On the frequency of protein glycosylation, as deduced from analysis of the SWISS-PROT database. Biochim Biophys Acta. 1999;1473(1):4-8.

68. Elliott S, Chang D, Delorme E, Eris T, Lorenzini T. Structural requirements for additional $\mathrm{N}$-linked carbohydrate on recombinant human erythropoietin. J Biol Chem. 2004;279(16):16854-16862.

69. Imperiali B, Hendrickson TL. Asparagine-linked glycosylation: specificity and function of oligosaccharyl transferase. Bioorg Med Chem. 1995;3(12):1565-1578.

70. Van den Steen P, Rudd PM, Dwek RA, Van Damme J, Opdenakker G. Cytokine and protease glycosylation as a regulatory mechanism in inflammation and autoimmunity. Adv Exp Med Biol. 1998;435:133-143.

71. Hurtado-Guerrero R, Dorfmueller HC, van Aalten DM. Molecular mechanisms of O-GlcNAcylation. Curr Opin Struct Biol. 2008;18(5): 551-557.

72. Egrie JC, Browne JK. Development and characterization of novel erythropoiesis stimulating protein (NESP). Nephrol Dial Transplant. 2001;16 Suppl 3:3-13.

73. Elliott S, Egrie J, Browne J, et al. Control of rHuEPO biological activity: the role of carbohydrate. Exp Hematol. 2004;32(12):1146-1155.

74. Egrie JC, Dwyer E, Browne JK, Hitz A, Lykos MA. Darbepoetin alfa has a longer circulating half-life and greater in vivo potency than recombinant human erythropoietin. Exp Hematol. 2003;31(4):290-299.

75. Sasu BJ, Hartley C, Schultz H, et al. Comparison of epoetin alfa and darbepoetin alfa biological activity under different administration schedules in normal mice. Acta Haematol. 2005;113(3):163-174.

76. Coccia MA, Cooke K, Stoney G, et al. Novel erythropoiesis stimulating protein (darbepoetin alfa) alleviates anemia associated with chronic inflammatory disease in a rodent model. Exp Hematol. 2001; 29(10):1201-1209.

77. Macdougall IC, Gray SJ, Elston O, et al. Pharmacokinetics of novel erythropoiesis stimulating protein compared with epoetin alfa in dialysis patients. J Am Soc Nephrol. 1999;10(11):2392-2395.

78. Smalling R, Foote M, Molineux G, Swanson SJ, Elliott S. Drug-induced and antibody-mediated pure red cell aplasia: a review of literature and current knowledge. Biotechnol Annu Rev. 2004;10:237-250.

79. Wide L, Wikstrom B, Eriksson K. A new principle suggested for detection of darbepoetin-alpha (NESP) doping. Ups J Med Sci. 2003;108(3):229-238.

80. Elliott S. Glycoengineering of Erythropoietin. Post-Translational Modification of Protein Biopharmaceuticals. Weinheim, Germany. Wiley-Blackwell; 2009:295-317.

81. de Boer R, Clemens M, Renczes G, et al. Phase I/II randomised study of a novel erythropoiesis-stimulating agent (AMG 114) for the treatment of anaemia with concomitant chemotherapy in patients with non-myeloid malignancies. Med Oncol. 2011;28(4):1210-1217.

82. Macdougall IC. CERA (Continuous Erythropoietin Receptor Activator): a new erythropoiesis-stimulating agent for the treatment of anemia. Curr Hematol Rep. 2005;4(6):436-440.

83. Haselbeck A, Bailon P, Pahlke W. The discovery and characterization of CERA, an innovative agent for the treatment of anemia. Blood. 2002;100(Abstract 857):227A.

84. Fishbane S, Tare N, Pill J, Haselbeck A. Preclinical pharmacodynamics and pharmacokinetics of CERA (Continuous Erythropoietin Receptor Activator), an innovative erythropoietic agent for anemia management in patients with kidney disease. J Am Soc Nephrol. 2003; 14(Abstract SA-FC 123):27A.

85. Macdougall IC, Robson R, Opatrna S, et al. Pharmacokinetics and pharmacodynamics of intravenous and subcutaneous continuous erythropoietin receptor activator (CERA) in patients with chronic kidney disease. Clin J Am Soc Nephrol. 2006;1(6):1211-1215.

86. Curran MP, McCormack PL. Methoxy polyethylene glycol-epoetin beta: a review of its use in the management of anaemia associated with chronic kidney disease. Drugs. 2008;68(8):1139-1156. 
87. Molineux G. The design and development of pegfilgrastim (PEG-rmetHuG-CSF, Neulasta). Curr Pharm Des. 2004;10(11): 1235-1244.

88. Macdougall IC, Bailon P, Tare N. CERA (Continuous Erythropoiesis Receptor Activator) for the treatment of renal anemia: an innovative agent with unique receptor binding characteristics and prolonged serum half-life. J Am Soc Nephrol. 2003;14(Abstract SU-PO1063):479A.

89. El-Komy MH, Schmidt RL, Widness JA, Veng-Pedersen P. Differential pharmacokinetic analysis of in vivo erythropoietin receptor interaction with erythropoietin and continuous erythropoietin receptor activator in sheep. Biopharm Drug Dispos. 2011;32(5):276-288.

90. Bethencourt V. Merck joins the biotech game. Nat Biotech. 2009;27(2): 104-104.

91. Hamilton SR, Davidson RC, Sethuraman N, et al. Humanization of yeast to produce complex terminally sialylated glycoproteins. Science. 2006;313(5792):1441-1443.

92. Dorey E. Merck ditches biogeneric. Nat Biotech. 2010;28(7):636-636.

93. Wrighton NC, Farrell FX, Chang R, et al. Small peptides as potent mimetics of the protein hormone erythropoietin. Science. 1996;273(5274):458-464.

94. Barbone FP, Johnson DL, Farrell FX, et al. New epoetin molecules and novel therapeutic approaches. Nephrol Dial Transplant. 1999; 14 Suppl 2:80-84.

95. Wrighton NC, Balasubramanian P, Barbone FP, et al. Increased potency of an erythropoietin peptide mimetic through covalent dimerization. Nat Biotechnol. 1997;15(12):1261-1265.

96. Bouman-Thio E, Franson K, Miller B, et al. A phase I, single and fractionated, ascending-dose study evaluating the safety, pharmacokinetics, pharmacodynamics, and immunogenicity of an erythropoietin mimetic antibody fusion protein (CNTO 528) in healthy male subjects. J Clin Pharmacol. 2008;48(10):1197-1207.

97. Bugelski PJ, Capocasale RJ, Makropoulos D, et al. CNTO 530: molecular pharmacology in human UT-7EPO cells and pharmacokinetics and pharmacodynamics in mice. J Biotechnol. 2008;134(1-2):171-180.

98. Sathyanarayana P, Houde E, Marshall D, et al. CNTO 530 functions as a potent $\mathrm{EPO}$ mimetic via unique sustained effects on bone marrow proerythroblast pools. Blood. 2009;113(20):4955-4962.

99. Fan Q, Leuther KK, Holmes CP, et al. Preclinical evaluation of Hematide, a novel erythropoiesis stimulating agent, for the treatment of anemia. Exp Hematol. 2006;34(10):1303-1311.

100. Doss S, Schiller B. Peginesatide: a potential erythropoiesis stimulating agent for the treatment of anemia of chronic renal failure. Nephrol Nurs J. 2010;37(6):617-626.

101. Besarab A, Zeig SN, Martin ER, et al. An open-label, sequential, dosefinding study of peginesatide for the maintenance treatment of anemia in chronic hemodialysis patients. BMC Nephrol. 2012;13:95.
102. Fishbane S, Schiller B, Locatelli F, et al. Peginesatide in patients with anemia undergoing hemodialysis. $N$ Engl J Med. 2013;368(4): 307-319.

103. Macdougall IC, Provenzano R, Sharma A, et al. Peginesatide for anemia in patients with chronic kidney disease not receiving dialysis. N Engl J Med. 2013;368(4):320-332.

104. Woodburn KW, Fan Q, Winslow S, et al. Hematide is immunologically distinct from erythropoietin and corrects anemia induced by antierythropoietin antibodies in a rat pure red cell aplasia model. Exp Hematol. 2007;35(8):1201-1208.

105. Macdougall IC, Rossert J, Casadevall N, et al. A peptide-based erythropoietin-receptor agonist for pure red-cell aplasia. $N$ Engl $J$ Med. 2009;361(19):1848-1855.

106. Elliott S, Lorenzini T, Yanagihara D, Chang D, Elliott G. Activation of the erythropoietin (EPO) receptor by bivalent anti-EPO receptor antibodies. J Biol Chem. 1996;271(40):24691-24697.

107. Schneider H, Chaovapong W, Matthews DJ, et al. Homodimerization of erythropoietin receptor by a bivalent monoclonal antibody triggers cell proliferation and differentiation of erythroid precursors. Blood. 1997;89(2):473-482.

108. Liu Z, Stoll VS, Devries PJ, et al. A potent erythropoietin-mimicking human antibody interacts through a novel binding site. Blood. 2007;110(7):2408-2413.

109. Lacy SE, DeVries PJ, Xie N, Fung E, Lesniewski RR, Reilly EB. The potency of erythropoietin-mimic antibodies correlates inversely with affinity. J Immunol. 2008;181(2):1282-1287.

110. Zhang H, Wilson IA, Lerner RA. Selection of antibodies that regulate phenotype from intracellular combinatorial antibody libraries. Proc Natl Acad Sci U S A. 2012;109(39):15728-15733.

111. Sytkowski AJ, Lunn ED, Davis KL, Feldman L, Siekman S. Human erythropoietin dimers with markedly enhanced in vivo activity. Proc Natl Acad Sci U SA. 1998;95(3):1184-1188.

112. Sytkowski AJ, Lunn ED, Risinger MA, Davis KL. An erythropoietin fusion protein comprised of identical repeating domains exhibits enhanced biological properties. J Biol Chem. 1999;274(35): 24773-24778.

113. Bitonti AJ, Dumont JA, Low SC, et al. Pulmonary delivery of an erythropoietin $\mathrm{Fc}$ fusion protein in non-human primates through an immunoglobulin transport pathway. Proc Natl Acad Sci U S A. 2004;101(26):9763-9768.

114. Dumont JA, Bitonti AJ, Clark D, Evans S, Pickford M, Newman SP. Delivery of an erythropoietin-Fc fusion protein by inhalation in humans through an immunoglobulin transport pathway. J Aerosol Med. 2005;18(3):294-303.
Biologics: Targets \& Therapy

\section{Publish your work in this journal}

Biologics: Targets \& Therapy is an international, peer-reviewed journal focusing on the patho-physiological rationale for and clinical application of Biologic agents in the management of autoimmune diseases, cancers or other pathologies where a molecular target can be identified. This journal is indexed on PubMed Central, CAS, EMBase, Scopus

\section{Dovepress}

and the Elsevier Bibliographic databases. The manuscript management system is completely online and includes a very quick and fair peerreview system, which is all easy to use. Visit http://www.dovepress. com/testimonials.php to read real quotes from published authors. 